\title{
Environmental performance scenarios in the production of hollow glass containers for food packaging: an LCA approach
}

\author{
Teodoro Gallucci ${ }^{1}$ - Giovanni Lagioia ${ }^{1} \cdot$ Paolo Piccinno $^{2}$ - Amedeo Lacalamita ${ }^{2}$ - Andrea Pontrandolfo ${ }^{1}$. \\ Annarita Paiano ${ }^{1}$ (1)
}

Received: 6 March 2020 / Accepted: 23 July 2020 / Published online: 3 August 2020

(C) The Author(s) 2020

\begin{abstract}
Purpose The importance of glass in the production of food packaging has stimulated the assessment of its impact. This study evaluates the environmental performance of hollow glass production in a manufacturing plant operating in Apulia (Italy), compares baseline and two alternative scenarios based on the life cycle assessment (LCA) method and proposes more environmentally friendly options.

Methods The LCA study was performed on primary data provided by a company for 2017 and secondary data retrieved from databases. The LCA was conducted according to ISO 14040:2006 and 14044:2018 with product category rule (PCR) basic module CPC 37. A midpoint approach was chosen. The software selected for the analysis was GaBi thinkstep AG version 8.7.0.18. The study was performed from cradle to grave, and the functional unit considered was $1 \mathrm{~kg}$ of finished hollow glass. Results and discussion A comparative analysis of the different scenarios was conducted considering seven environmental impact indicators. The results highlight major improvements in the environmental impact indicators: in particular, the replacement of raw materials with cullets would yield significant improvements if all of the cullets are recovered in the regional territory. These improvements, as confirmed by the results of Scenario 2, could be further increased both by the use of renewable energy such as photovoltaic (PV) energy and by technological improvements such as lightweighting.

Conclusions Through the LCA, the authors quantified the potential environmental impact associated with the production of hollow glass, thereby identifying solutions and formulating suggestions to reduce the environmental impacts associated with food packaging. The evaluation of the different scenarios could help managers in the decision-making process, thus improving the environmental performance of both the process and final product.
\end{abstract}

Keywords Hollow glass $\cdot$ Food packaging $\cdot$ Life cycle assessment $\cdot$ Recycling $\cdot$ Lightweighting $\cdot$ PV energy

\section{Introduction}

In recent decades, we have witnessed a constant growth in the world population, which implies a greater demand for food production (Caldeira et al. 2019). The increasing need to produce more food to satisfy the growing world demand has led

Responsible editor: Carlo Ingrao

Annarita Paiano

annarita.paiano@uniba.it

1 Department of Economics, Management and Business Law, University of Bari Aldo Moro, Largo Abbazia Santa Scolastica, 53-70124 Bari, Italy

2 P\&R Project, via Martinelli Diego 24, 70018 Rutigliano, BA, Italy to a major increase in the production of food packaging materials, thus imposing a great pressure on natural resources with their consequent depletion (Fresán et al. 2019). Food packaging exerts direct and indirect environmental impacts on the supply chain (Molina-Besch et al. 2019). Considering that packaging has to preserve food ingredients and nutrients throughout the product journey along the supply chain (Del Borghi et al. 2016), the challenge for many researchers is the determination of alternative, innovative and technologically advanced solutions that can help minimize its associated environmental impacts.

Glass is one of the safest and most suitable food packaging materials because it does not deform; it is suitable for sterilization and cleaning processes and has several essential properties, such as transparency, excellent insulating capacity, hygienic guarantees, chemical inertia, impermeability and zero chemical 
interactions with food (Kobayashi 2016a). For these reasons, glass containers have been adopted for many years for both food and beverage packaging (Franco and Falqué 2016).

Packaging is a substantial part of food preservation and minimizes bacterial proliferation throughout the shelf life. Jayamanne and Adams (2004) and Cruz et al. (2007) studied the importance of packaging materials on the stability of probiotic dairy products, and after comparing the use of glass and plastic packaging materials during product storage, they concluded that glass packaging benefits the survival of probiotic cultures owing to its extremely low oxygen permeability and should be preferred. Furthermore, Balzarotti et al. (2015) highlighted that despite the wide range of packaging materials on the market, consumers continue to prefer glass packaging because the weight and firmness of food packaging have been shown to affect consumer judgement.

Worldwide, glass packaging accounts for $24 \%$ of total beverage packaging and $40 \%$ of total food packaging (Vinci et al. 2019a).

Glass is also considered a permanent material that can be endlessly recycled into new packaging while maintaining its safety features, thus achieving the concept of a circular economy. However, glass has its disadvantages, such as its fragility and high transport costs (Kobayashi 2016b; Vinci et al. 2019b). Furthermore, the glass industry is very $\mathrm{CO}_{2}$-intensive (Assovetro 2020): in Italy, the $\mathrm{CO}_{2}$ emissions amounted to $1,775,643 \mathrm{t}$ in 2018 , accounting for $11 \%$ of the industrial emissions (considering the mineral, chemical and metal sectors) and $0.53 \%$ of the total Italian emissions. These numbers support the need to reduce the negative environmental impact of the entire supply chain (Schmitz et al. 2011).

In Italy, hollow glass production accounts for more than $80 \%$ of the total glass production, which is equal to $5,342,046 \mathrm{t}$ (Assovetro 2019). An analysis of the Italian hollow glass market (Fig. 1) reveals that the production trend over 15 years has remained constant. The industrial glass sector in Italy occupies a major position in the European Union with approximately 26 plants, out of a total of 144 plants across Europe (approximately 18\%), as reported by The European Container Glass Federation (FEVE 2020); in terms of the production volume, Italy at 4.3 Mt represents approximately $20 \%$ of the total European container glass production, which amounts to approximately $21 \mathrm{Mt}$.

The Italian hollow glass production is largely linked to the food sector; indeed, approximately $93 \%$ of the hollow glass production is represented by bottles and food jars, as indicated in Table 1.

To better understand this market, it is necessary to focus our attention on the glass use in Italy. Figure 2 shows a slow but significant increase in glass consumption over the decade of 2008-2018; hollow glass consumption increased by $15.6 \%$.

With increasing glass use, it has become necessary to increase its recycling (Moraga et al. 2019), thus guaranteeing a reduction in the use of virgin raw materials in the production process (Blengini et al. 2012). Indeed, the recycling rate of glass has increased over the years in Italy, from 38.8\% in 1998 to $76.3 \%$ in 2018 (FEVE 2019), thereby surpassing the European average rate of $74.5 \%$ (Eurostat 2020), notwithstanding countries such as Belgium, Denmark, Finland or Sweden, which have exhibited higher rates (approximately 95\%).

This study evaluates, through the life cycle assessment (LCA) methodology, the environmental performance of hollow glass packaging for beverages and food and compares baseline and alternative scenarios proposing the use of renewable energy carriers, lightweighting and increased cullet use. It is important to note that cullets refer to internal and external waste glass. The former pertains to glass manufacturing and includes production offcuts and products rejected by quality; instead, external cullets (post-consumer) are collected at public glass waste collection points.
Fig. 1 Hollow glass production in Italy $(t)$. Source: personal elaboration by the authors on FEVE (2015); Assovetro (2019)

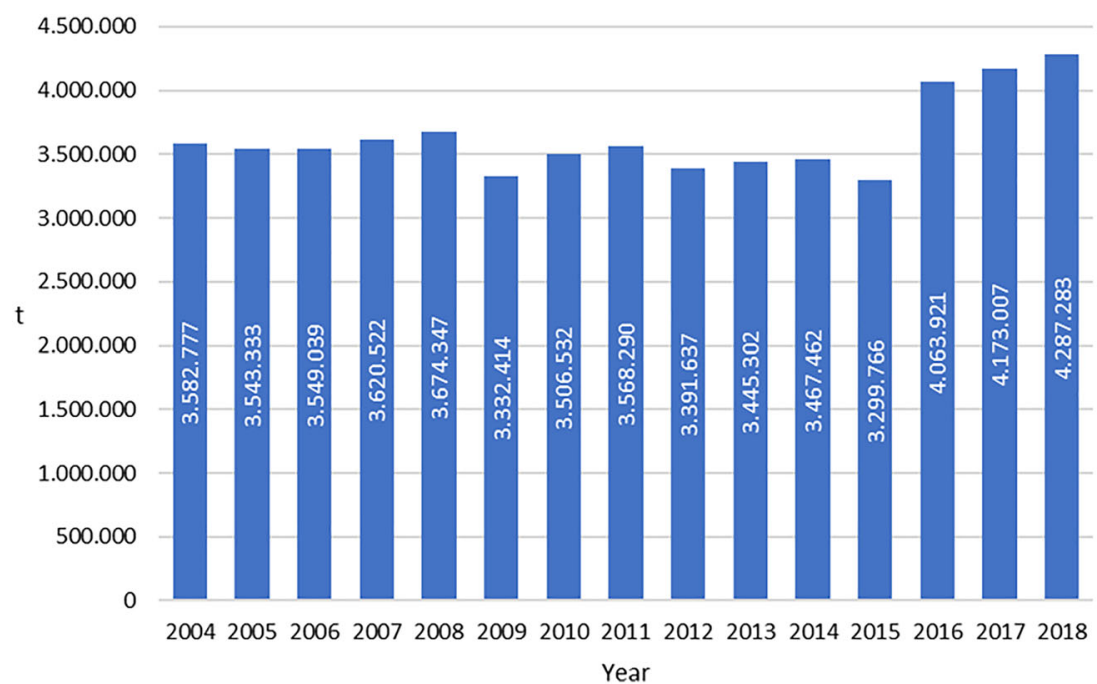


Table 1 Hollow glass product categories. Source: Assovetro (2019)

\begin{tabular}{lrr}
\hline Product categories & \multicolumn{1}{l}{ r } \\
\hline Bottles & $3,685,543$ & 86 \\
Flacons & 177,429 & 4 \\
Food jars & 281,718 & 7 \\
Articles for domestic use & 142,593 & 3 \\
Total & $4,287,283$ & 100 \\
\hline
\end{tabular}

Thanks to knowledge of the field, the study also underlines how the separation of cullets from other waste prior to collection and by colour at the platform after collection and prior to recycling could yield environmental advantages. For this reason, this study analyses data on the recovery of post-consumer cullets in the Apulia region as feedstock for a manufacturing plant under consideration.

Data from the regional Apulia agency (Osservatorio Rifiuti Regione Puglia 2020) indicate that in 2019, the differentiated collection amount of glass packaging totalled 96,111 t. Considering that its trend increased at an average annual rate of $12.7 \%$ over the last 3 years, a differentiated glass collection amount of approximately 137,577 t in 2022 can be estimated. Consequently, we can assume that, within a short period, a large part of the cullet requirements in this study will be guaranteed. In particular, in Apulia, three hollow glass manufacturing plants occur, one of which is the company assessed in this study with another company of a similar capacity, whereas the third glass manufacturing plant is very small. Hence, the cullet supply available in Apulia is currently mainly processed by the two largest plants. At present, collected cullets are sent to regional platforms for storage and sale under $\mathrm{CoReVe}$ coordination, which is the national consortium for the collection, recycling and recovery of cullets produced within the national territory.
The present study has performed an LCA analysis examining the current hollow glass packaging production of a selected manufacturing plant to propose improvements scheduled as two increase steps of environmental savings. In particular, two realistic scenarios were defined, according to the increase in raw material, energy and emission savings, over a current scenario i.e. the baseline scenario. The first scenario considered a growth in cullet use, whereas the second scenario included a mass reduction in finished products and photovoltaic (PV) energy use, as mentioned above.

This study, therefore, provides investment suggestions for management from an environmental point of view. Furthermore, the reduction in the global warming potential, considered under the defined scenarios, leads to major economic and financial enhancements due to the reduction in $\mathrm{CO}_{2}$ eq emissions in the emission trade system (ETS).

Consequently, the choice between different scenarios at the production stage allows the better implementation and management of the challenges a company might wish to address, according to the need for environmental improvement and based on option costs. In light of the last consideration, the establishment of the above scenarios considers the practices and actions that do not demand a great economic investment from companies; currently, companies are increasingly searching for ways to reduce environmental impacts while avoiding additional costs.

\section{A non-exhaustive review of the main studies related to the environmental performance of glass packaging using LCA}

A lack of research analysis is indicated by the literature review on the environmental impacts of the glass packaging supply chain. Vellini and Savioli (2009) assessed the energy
Fig. 2 Historical series of consumption and recycling of glass packaging in Italy $(\mathrm{kt})$ Sources: Grisan (2018); FEVE (2015); CoReVe (2019a)

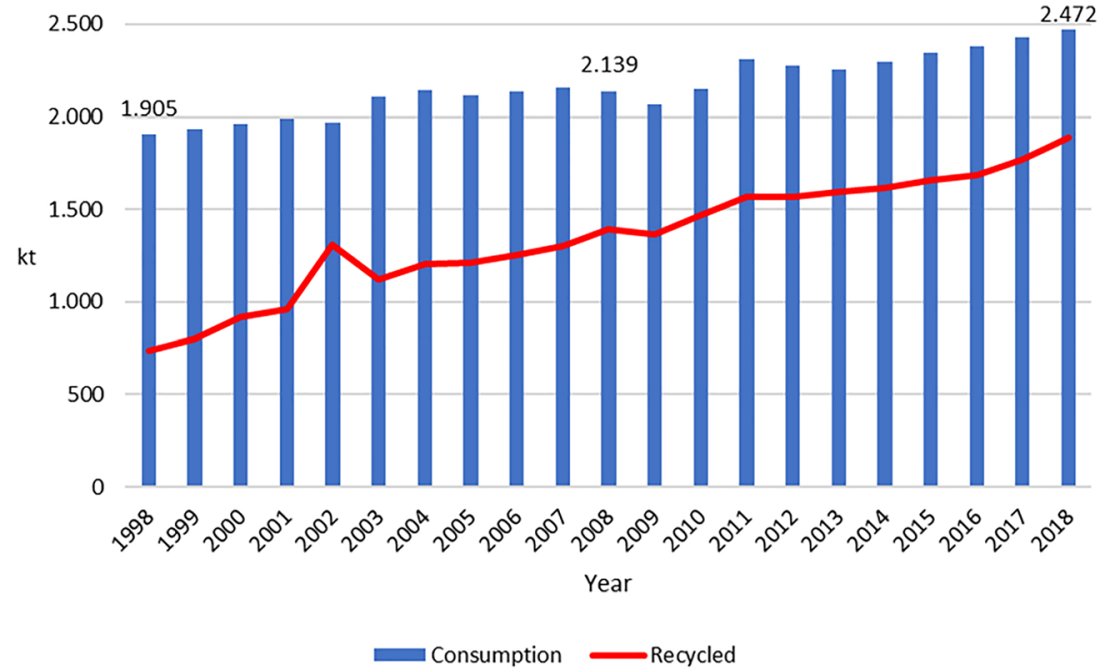


consumption during the production of glass containers through the LCA methodology with the goal of determining the best glass recycling scenario. Humbert et al. (2009) compared two alternative solutions, namely, glass jars and plastic pots, for baby food packaging through an LCA study. The results revealed that plastic pots exhibit a slight advantage over glass jars in terms of environmental impacts. Additionally, Accorsi et al. (2015) investigated the environmental impacts of alternative packaging solutions, comparing glass with plastic packaging, whereas Guiso et al. (2016) also assessed the impacts of tin-plated steel cans for extra virgin olive oil: the authors found that glass packaging is the most sustainable choice for local distribution, while tin-plated steel cans are better suited for long distance transport. Garfi et al. (2016) evaluated the environmental impacts imposed by drinking water packaging in Spain, by developing five different scenarios, including a scenario related to mineral water in glass bottles. Manfredi and Vignali (2014) conducted an LCA study concerning tomato puree packaging. Their study considered the entire production process from the cultivation stage to the packaging and storage stages and emphasized the use of glass lightweighting as a potential improvement in regard to the environmental impact. Ingrao et al. (2019), in their LCA study of the tomato supply chain, underlined that virgin glass is the best option for tomato puree, namely ' $100 \%$ virgin glass is utilised for jar manufacturing due, in turn, to $100 \%$ transparency and purity required for the glass itself'. The glass transparency is very important because consumers want to see what they are buying, especially in the case of food products. The authors underline that in the present study, considering the typology of the glass packaging produced e.g. small bitter aperitif bottles, a transparency level of $100 \%$ is not necessary and, therefore, cullets can be used. Consequently, the use of cullets does not affect the glass quality because it corresponds to the customer demand and marketing requirements.

Neto et al. (2013) performed an LCA study based on the Portuguese wine supply chain, highlighting the need for a better understanding of the peculiarities and use of resources connected to the processing of cullets through collaboration with the glass production industry. Freire et al. (2001), through an approach based on life cycle activity analysis (LCAA), evaluated the use of cullets for glass production, thereby emphasizing practical aspects, material costs and transport and collection methods and highlighting both the negative and positive aspects of cullet use.

Markwardt and Wellenreuther (2016) conducted a comparative LCA study of different food packaging options and stressed how the use of renewable raw materials is as useful and advantageous as the use of renewable energy sources in the production of food packaging. Amienyo et al. (2014) assessed any improvements applicable to the production of glass wine bottles in two techniques: the use of recycled glass and lightweighting. Specifically, the authors highlighted that 'for each $10 \%$ increase in the amount of recycled glass, the GWP is reduced by $2 \%$ ' and 'reducing the weight of glass bottles by $10 \%$ results in GWP savings of about $4 \%$ or $43 \mathrm{~g}$ $\mathrm{CO}_{2}$ eq per bottle'. These reduction data are much lower than the results in our paper, probably due to the functional unit considered, which is a bottle of red wine in the reviewed paper, and to the incidence of glass packaging of only $20 \%$ of the total GWP; consequently, the packaging improvement, through the application of more recycled glass and lightweighting, reported by Amienyo et al. (2014) imposed a smaller influence on the total GWP than that suggested in our results.

Del Borghi et al. (2016) summarized 35 scientific studies in 4 categories: (1) stakeholder perception of packaging; (2) material choice; (3) packaging eco-design and (4) end-of-life scenarios.

In the first category, the authors emphasized that although glass is perceived as sustainable packaging by consumers, the associated high environmental impacts are often not considered. This issue affects the improvements of materials used because if stakeholders do not demand a change, decision makers and manufacturers will not implement any.

The most numerous papers occurred in the third category, and the authors reported that the production of lighter bottles is evaluated in many LCA studies performed on the wine industry. This aspect is similar to our hypothesis of lightweighting, although different weight reduction rates were reported, namely, 5\% in our paper and 30\% in Point et al. (2012).

The same authors stressed in their conclusion that most LCAs conducted on glass packaging relied on secondary data from the EcoInvent database. A high percentage of fossil energy sources affects the environmental score of glass, while the considered ecodesign and new glass materials or alloys improve the environmental performance, thus reducing the mechanical performance of traditional glass and supporting our assumptions.

Nevertheless, it is worth noting that worldwide, certain glass industry associations conducted LCA studies over a 10 -year period. In 2010, two important LCA studies based on primary data of container glass were conducted by the Glass Packaging Institute (GPI 2010) and FEVE (2010). The GPI conducted the analysis using data from 105 manufacturing plants located in North America, while the data analysed in the European Container Glass Federation (FEVE) study concerned more than 200 European manufacturing plants. Both studies were conducted with a cradle-to-cradle approach with $1 \mathrm{~kg}$ of formed and finished glass as the functional unit. Furthermore, Finkbeiner (2012) identified potential gaps and limitations of the LCA methodology, by comparing different packaging materials in relation to the FEVE 2010 study. 
Several years later, FEVE performed another LCA study in which the use of cullets to reduce $\mathrm{CO}_{2}$ emissions was highlighted (FEVE 2016). Another significant LCA study by Owens-Illinois (Avery et al. 2017) reported primary data from four global regions (North America, Latin America including Mexico, the European Union and Asia-Pacific) totalling 78 plants operated by Owens-Illinois; contrary to the previous studies, the above LCA approach occurred from cradle to gate plus end of life.

As deduced from the literature overview, these technical reports employed the LCA methodology to study glass production (such as float glass, container glass, glass wool and other glass including hollow glass), whereas most of the scientific literature focused on comparing glass and plastic packaging materials or determining the environmental performance of glass packaging recycling. For this reason, there are few scientific environmental LCA studies of hollow glass production. Indeed, the authors noted that the literature results cannot be benchmarked against the paper's results because of differences in system boundaries or functional units. To bridge this gap, a comparison of our results to those from technical reports has been conducted in the Discussion section. This adds to the novelty of this paper because the results provide updated LCA data on hollow glass production. Furthermore, we provide a suitable and replicable model through contextualization of the case study at the territorial level. Moreover, the present study attempts to offer new evidence for hollow glass production, not by developing innovative technical solutions of production activities but by improving the conventional process focusing on the differing performance levels of the production chain. This improvement is based on approaches integrating the circular economy and eco-design, additionally enhanced with the use of renewable energy carriers. Hence, the defined scenarios regard hollow glass production integrating the use of PV energy and the lightweighting option and the replacement of raw materials with cullets.

\section{Materials and method}

\subsection{Goals and scope}

The aim of this study was to evaluate the environmental performance of hollow glass production for beverage and food packaging in a manufacturing plant operating in Apulia (Italy) by comparing baseline and alternative scenarios. The company involved, Vetrerie Meridionali (VeMe) S.p.a., located in Castellana Grotte (BA), Italy, has been working in the hollow glass sector for over 40 years. Its annual production equals $130,000-140,000$ tons.

The LCA performed was based on the glass production cycle of the company in regard to transparent glass containers for beverages and foodstuffs. It was conducted in accordance with ISO 14040: 2006 and 14,044: 2018, with the PCR basic module of CPC 37 for glass and glass products and other nonmetallic products n.e.c. version 3.0 (Environdec 2018). The software used was GaBi thinkstep AG version 8.7.0.18, including the EcoInvent integrated 3.3 database. The latest available version of CML 2001 (January 2016 version) was implemented to assess the environmental impact, and the functional unit was $1 \mathrm{~kg}$ of finished hollow glass.

The following scenarios were considered:

The baseline scenario was defined according to the current production cycle, which uses cullets as $32 \%$ of the total raw materials and the Italian energy mix as the energy carrier; scenario 1 implemented cullet recycling, in addition to postconsumer material from the regional supply, up to $66 \%$ of the raw materials, and the energy mix of the baseline was maintained; scenario 2 considered the same rate of cullet usage (66\%), a lightweighting level of 5\% and PV energy use as a total replacement of the Italian energy mix for electricity production (Fig. 3). Under this scenario, we decided to aggregate the above three variables because the impact of lightweighting is smaller than that of the use of PV energy and cullets.

Before simulating these scenarios, certain preconditions related to the technical aspects of the plant system were verified. The possibility of increasing the cullet utilization level from 32 to $66 \%$ was hypothesised considering the technical characteristics and capacity of the plant furnace. The furnace was a fluidized-bed end port-type furnace with burners and rear chambers for heat recovery and could use even more than $66 \%$ of cullets in the batch mode. The only required precaution was to add cullets separately from the raw batch materials to avoid damaging the equipment used for the transport of the batch and to decrease the risk of contaminating the melt with impurities.

The company required a study of the baseline production prior to considering and evaluating different solutions that would improve the environmental performance, with the ultimate goal of attaining the circularity principles of the production system. In this regard, LCA was conducted to define and compare various technological and energy solutions to address managerial innovations within the production process. The technological solutions considered both an increased quantity of cullets and lightweighting, which involves the weight reduction or mass reduction in the finished product (Butler and Hooper 2019); in this case, a lightweighting level

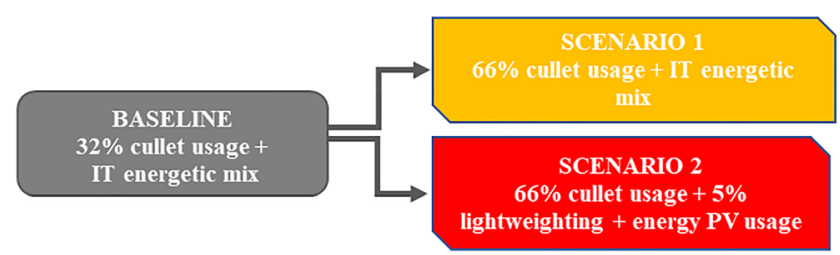

Fig. 3 Flowchart of the scenarios 
of only $5 \%$ was considered to not compromise the resistance characteristics of the finished product, according to company manager information. The energy solution considered the replacement of the current Italian energy mix with PV energy. In particular, all electricity used, equal to over 191 TJ per year (Table 2), was covered by the use of PV energy.

\subsection{Description of the production process}

The production process of the plant can be split, as shown in Fig. 4

The raw materials are stored in different silos located outside the plant and transported for production using four hoppers; eight extra hoppers are implemented to load and measure the cullet quantity. Two end port-type melting furnaces with burners and rear chambers are also available for heat recovery. Each melting furnace supplies three production lines of hollow glass.
After leaving the melting furnace, the conditioning phase follows, which consists of controlled cooling of the vitreous mass down to the drop temperature, normally between $1000{ }^{\circ} \mathrm{C}$ and $1250{ }^{\circ} \mathrm{C}$. The molten liquid flows into thermal conditioning channels. Once the appropriate viscosity is reached, the vitreous mass is cut into drops of a size and weight proportional to the object to be created. Once cut-off from the shears, drops of incandescent glass (approximately $1200{ }^{\circ} \mathrm{C}$ ) fall onto the moulds of a forming machine. The manufacturing process of glass containers can either be blowing or pressure-blowing. Once the product is formed by blowing, the resulting product is transported along the line for the subsequent heat treatment (to reduce the formation of micro-cracks responsible for the deterioration of the mechanical resistance characteristics), re-annealing (to reduce the tension in the vitreous mass, which could induce an unsafe mechanical fragility in the glass product), cold treatment (to

Table 2 Main inputs and outputs in hollow glass annual production and EcoInvent reference modules

\begin{tabular}{|c|c|c|c|}
\hline Input/output & Unit & Amount & EcoInvent module* \\
\hline \multicolumn{4}{|l|}{ INPUT } \\
\hline \multicolumn{4}{|l|}{ Raw materials } \\
\hline Cullet & $\mathrm{kg}$ & $5.75 \mathrm{E}+07$ & Market for waste glass (EUROPE) \\
\hline Yellow sand & $\mathrm{kg}$ & $6.05 \mathrm{E}+07$ & Market for sand (GLO) \\
\hline Soda & $\mathrm{kg}$ & $2.08 \mathrm{E}+07$ & Soda ash, dense, to generic market for neutralising agent (GLO) \\
\hline Calcium carbonate & $\mathrm{kg}$ & $1.47 \mathrm{E}+07$ & Market for calcium carbide, technical grade (GLO) \\
\hline Dolomite & $\mathrm{kg}$ & $1.02 \mathrm{E}+07$ & Dolomite production (ROW) \\
\hline Sand V3-U & $\mathrm{kg}$ & $1.53 \mathrm{E}+07$ & Market for sand (GLO) \\
\hline \multicolumn{4}{|l|}{ Packaging materials } \\
\hline Cardboard tray & $\mathrm{kg}$ & $1.18 \mathrm{E}+05$ & Carton board box production service, with offset printing (ROW) \\
\hline Stretch film & $\mathrm{kg}$ & $4.48 \mathrm{E}+05$ & Fleece production, polyethylene (RER) \\
\hline Wooden pallet & $\mathrm{kg}$ & $5.01 \mathrm{E}+06$ & Plywood production, for outdoor use (RER) \\
\hline Alveolar board (PP) & $\mathrm{kg}$ & $2.11 \mathrm{E}+06$ & Polypropylene production, granulate (RER) \\
\hline \multicolumn{4}{|l|}{ Others } \\
\hline Acetylene & $\mathrm{kg}$ & $1.30 \mathrm{E}+04$ & Acetylene production (ROW) \\
\hline Difluoroethane & $\mathrm{kg}$ & $4.22 \mathrm{E}+03$ & Difluoroethane production, HFC-152a (ROW) \\
\hline Water treatment & $\mathrm{kg}$ & $1.98 \mathrm{E}+04$ & Tap water production, conventional with biological treatment (EUROPE) \\
\hline Polyglass & $\mathrm{kg}$ & $1.68 \mathrm{E}+03$ & Chemical production, inorganic (GLO) \\
\hline \multicolumn{4}{|l|}{ Energy resources } \\
\hline Electrical energy & GJ & $1.91 \mathrm{E}+05$ & Market for electricity, high voltage (IT) \\
\hline Natural gas & GJ & $8.49 \mathrm{E}+05$ & Market for heat, district or industrial, natural gas (GLO) \\
\hline Diesel fuel & GJ & $2.65 \mathrm{E}+03$ & Market for diesel (EUROPE) \\
\hline \multicolumn{4}{|l|}{ Output } \\
\hline Emulsions & $\mathrm{kg}$ & $1.21 \mathrm{E}+02$ & Market for waste mineral oil $\{$ EUROPE\} \\
\hline Iron and steel & $\mathrm{kg}$ & $1.19 \mathrm{E}+02$ & Market for waste reinforcement steel (ROW) \\
\hline Plastic & $\mathrm{kg}$ & $8.14 \mathrm{E}+01$ & Market for waste plastic, mixture (EUROPE) \\
\hline Rainwater & $\mathrm{kg}$ & $5.84 \mathrm{E}+01$ & Market for wastewater, average (EUROPE) \\
\hline Others & $\mathrm{kg}$ & $2.02 \mathrm{E}+02$ & - \\
\hline
\end{tabular}

*RER corresponds to Europe, $I T$ to Italy, Europe to Europe without Switzerland, GLO to global, $R O W$ to rest of the world 
Fig. 4 Production process flow

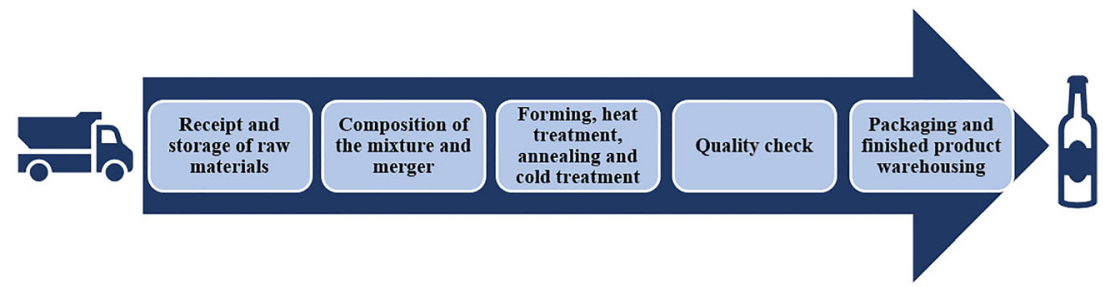

reduce the friction coefficient of the containers, thereby improving their smoothness along the line) and packaging processes.

\subsection{System boundary}

The system boundaries are those identified by the CPC 37 PCR and by other study typologies (Vinci et al. 2019a, b; Auer et al. 2017; Avery et al. 2017). Considering that the plant has obtained Environmental Product Declaration (EPD) certification, the cradle to grave analysis, excluding the final consumption phase, has been divided into three phases, namely, upstream, core and downstream phases.

As shown in Fig. 5, the upstream phase includes the procurement of raw materials, cullets and primary packaging materials, all of which constitute the composition of the material entering the core phase. The core phase includes the consumption of energy (electricity, natural gas and diesel) according to the domestic energy mix (the baseline scenario), the depletion of substances for maintenance and treatment, the transport of incoming raw materials and the haulage of the waste produced for recovery and other waste produced to the landfill. The downstream phase includes the transport of the finished product to the customer companies and the recycling and unloading of glass, following its use, once thrown into recycling or undifferentiated bins: the percentage considered to calculate the value of waste-recycled glass is equal to $76.3 \%$.

\subsection{Life cycle inventory analysis}

All inventoried data were based on primary data and on secondary data retrieved from databases with a reference year of 2017.

The primary data and product information (including material categories and amounts of the inputs and outputs and manufacturing processes) were site-specific data and provided by Vetrerie Meridionali and its suppliers. These data were mainly considered in the upstream and core phases.

Conversely, the secondary data (including raw materials and energy resource extraction, processing and refining, packaging and transport) were gathered from the EcoInvent database, whereas Eurostat (2019) was used for the cullet post use data.
Data for consumption of the energy carriers (electricity, natural gas and diesel) were site-specific, while their background data were retrieved from the EcoInvent database. No allocations or parameterizations were implemented.

The transport mode, origin and destination of the raw materials and products were provided by Vetrerie Meridionali (VeMe) S.p.a.

Primary data collection was conducted by sending a list of the data required for the analysis to the administrative office and subsequently by compiling specific data collections subdivided into homogeneous components. The data were shared with company project representatives for peer review to verify their correctness and consistency and to perform any related mass balances of the process phases. Finally, the primary data were combined with the secondary data to model and adapt the process.

We adopted a cut-off of $1 \%$ in relation to the material incoming and outgoing flows (raw materials, primary packaging, waste products and substances for maintenance and treatment). Thereafter, we verified that the cut-off excluded flows accounted for less than $1 \%$ of the environmental impacts calculated as required in the reference of the product category rules (PCRs).

Table 2 summarizes the detailed data concerning the main annual inputs and outputs generated at the core, upstream and downstream phases. Yellow sand and cullets exhibit the highest rates (33.6\% and 32\%, respectively) of the total raw materials. We underline that the current cullet supply $(57,500 \mathrm{t})$ includes both an internal supply, cullets from the production cycle of the company, at a rate of approximately $34 \%$ (approximately 20,000 t), and external supply at approximately $66 \%$ (37,500 t), of which $96 \%$ is obtained from other regions and only $4 \%$ is from Apulia.

The most important outputs are waste categories such as emulsions and steel and iron waste: these two categories together represent more than $40 \%$ of the total amount of the produced waste.

Difluoroethane is also considered an output because it is a process emission, which is treated and constantly monitored.

Another important consideration regards rainwater, which represents $10 \%$ of the total waste produced.

Under scenarios 1 and 2, all input and output have been reduced according to the information provided by the company.

The other data considered include the following: 


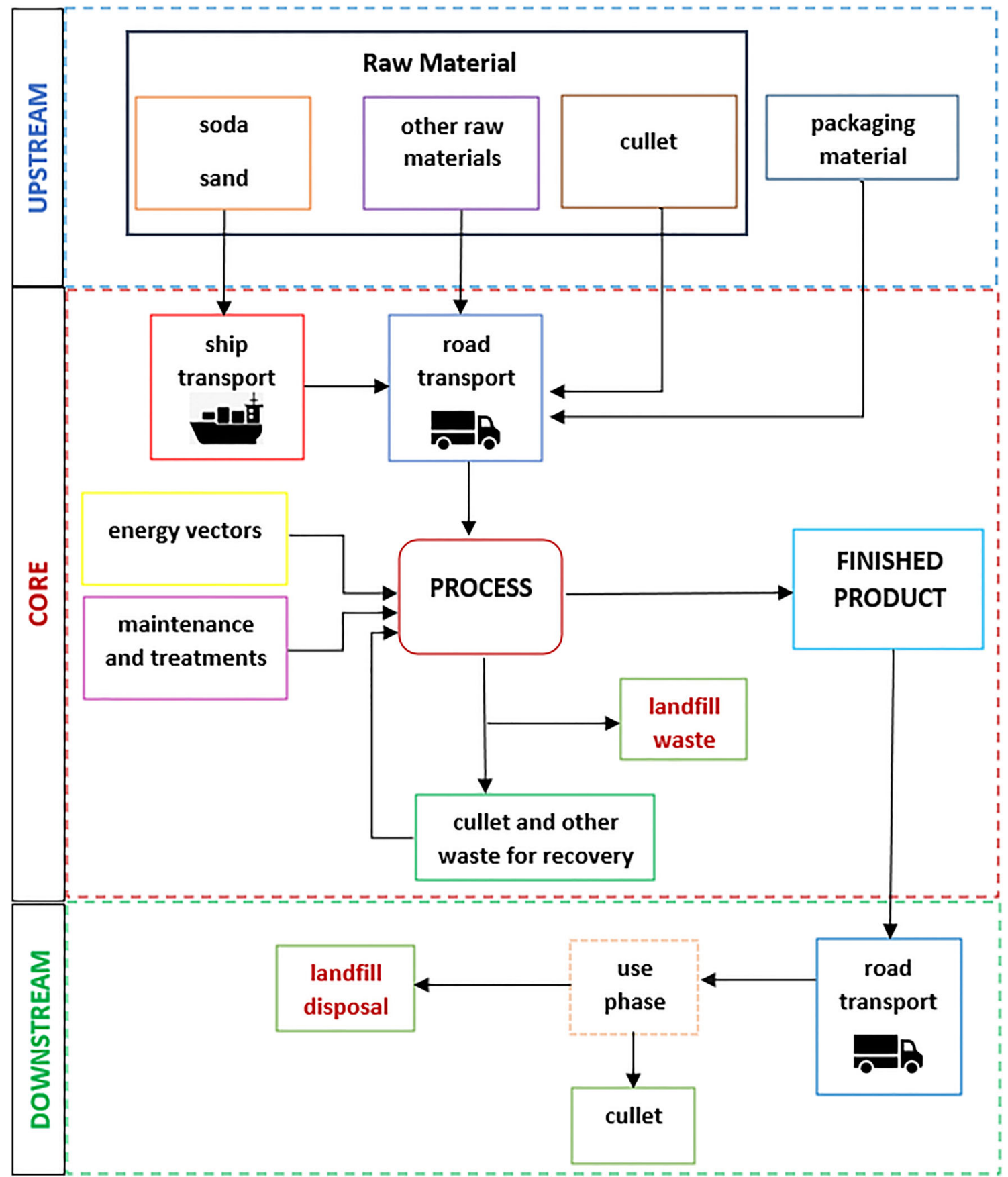

Fig. 5 System boundary considered in the hollow glass life cycle

Raw material transport The raw material stems almost entirely from Italian locations through tipper trucks with the exception of sand arriving from Sousse (Tunisia) on merchant ships arriving at the port of Monopoli (BA), which is then transported on tipper trucks to the plant. Soda arrives from Kazan (Ankara, Turkey) and follows the same procedure as that for sand transport, but the port of arrival is Bari (IT); part of the supplied sand originates in Porto Torres, located in another Italian region, also transported by merchant ships to the Monopoli (BA) port. The calculated value of ship transport is $1.610 \mathrm{t} / \mathrm{km}$, whereas the calculated value of road transport is $0.047 \mathrm{t} / \mathrm{km}$.

Packaging transport The calculation approach adopted for the transport of packaging materials is the same as that adopted for the raw material transport. In this case, the suppliers are located exclusively in Italian territories, and the value is $0.001 \mathrm{t} / \mathrm{km}$.

The energy carriers considered in the process are electric energy, natural gas (methane) and diesel, as indicated in 
Table 2. It should be noted that natural gas was the main energy carrier, accounting for over $81 \%$ of the total energy, while electricity and diesel accounted for approximately $18 \%$ and $0.25 \%$, respectively, of the total energy. The consumption data were obtained from specific meters housed at the plant and recorded by dedicated software. From these meters, it was possible to determine the consumption of electricity and natural gas per furnace, production line and other utilities (e.g. office machinery, air conditioning); moreover, no allocation was required because the entire production was represented by the hollow glass production considered in the study. The diesel consumption was measured using a meter at the supply tank. The data measured by the meter were expressed in litres; the conversion factor defined by the ENEA with reference to Legislative Decree 102/2014 and equal to $0.833 \mathrm{~kg} / \mathrm{l}$ was adopted for the conversion into $\mathrm{kg}$.

Waste transport: (a) from the plant to the landfill, for the waste derived from the production process and transported to the landfill; (b) from the collection points and platforms to the plant, for the cullets derived from the use of the finished product, which is then discarded into containers for separate collection. In both transport processes, the calculated value was $0.00104 \mathrm{t} / \mathrm{km}$.

Finished product transport to the customer The transport of the finished product includes both the distance covered by the transport carrier to reach the product distribution/sales platforms and the type of transport used. The data were acquired from the software used by the logistics department of the plant, and the calculated value was $0.00007 \mathrm{t} / \mathrm{km}$.

\subsection{Life cycle impact assessment}

The calculated impact categories according to the PCR basic module of CPC 37 for glass and glass products and other nonmetallic products n.e.c. version 3.0 are listed in Table 3.

The midpoint approach was implemented to quantify the life cycle impact assessment (LCIA) results.

\section{Results and discussion}

For all scenarios, the assessment and comparison of the environmental impacts from cradle to grave were performed. From the analysis of the results, alternative scenario 2 , characterised by the use of cullets, lightweighting and PV energy, improves all environmental indicators, as shown in Fig. 6: particularly, when the baseline scenario and scenario 2 are compared, the reduction in the first four impact indicators is very large, ranging from $52 \%$ of the POCP to $62 \%$ of the GWP, whereas in the comparison of Scenario 1 and the baseline scenario, small improvements are observed in all impact indicators, ranging from $4 \%$ of the ADP elements to approximately $44 \%$ of the AP.
In Table 4, the results are broken down by the environmental indicator and process phase per scenario.

In regard to the GWP indicator, we highlighted a total decrease of $41 \%$ when comparing scenario 1 with the baseline scenario; the main reductions occurred at both the upstream $(50 \%)$ and core (28\%) phases, whereas the value at the downstream phase remained unchanged under all scenarios. The reduction at the core phase was due to a decrease in the transportation of the raw materials and to the simultaneous increase in cullet use for glass melting in the two furnaces, which required more than $8 \%$ less energy.

Comparing scenario 2 with the baseline scenario, the total GWP was reduced by $62 \%$. It was the reduction at the core phase, equal to $76 \%$, particularly the use of PV energy, which affected this result.

Regarding the AP indicator, under scenario 1, compared with the baseline scenario, a $44 \%$ decrease was observed mainly due to an upstream phase reduction, while under scenario 2 , the improvement over the baseline scenario was approximately $61 \%$, mostly influenced by the core phase, at a reduction of approximately $75 \%$.

We should underline that in comparison with the baseline scenario, the EP indicator was reduced both at the upstream phase and at the core phase: the values decreased by $46 \%$ and $56 \%$ under scenarios 1 and 2, respectively.

Additionally, the POCP indicator exhibited a total decrease of over $47 \%$ under scenario 1 over the baseline scenario, whereas the decrease was equal to $52 \%$ under scenario 2 , of which the greatest reduction $(63 \%)$ occurred at the core phase.

In comparison with the baseline scenario, the results revealed a slight reduction in the environmental impacts in terms of the following indicators: the total water depletion decreased by $8.6 \%$ under scenario 2 , where the core phase showed the greatest reduction of $25 \%$; the total ADP elements were reduced by approximately $4 \%$ under scenario 2 , and the total ADP of fossil fuels revealed a reduction of over $12 \%$ under Scenario 2, affected by the reduction at the core phase of $39 \%$.

In general, from the analysis of the results listed in Table 4, the greatest reduction emerges at the upstream phase for each impact indicator, considering scenario 1 , which is the first step of the envisioned improvements, namely, the increase in cullet use, whereas the core phase shows the greatest decrease under scenario 2 for almost all impact indicators, mainly due to the $\mathrm{PV}$ energy replacing the Italian energy mix for energy generation. These considerations can also be explained through the data of the most impactful inputs, in particular raw materials and energy carriers, as shown in Fig. 7.

The characterisation results underscore the highest weight of calcium carbonate notably affecting the GWP, AP, EP and POCP under all scenarios, whereas the largest reduction occurs under scenario 1 over the baseline scenario. In particular, calcium carbonate exhibits the highest weight $(87 \%)$ under 
Table 3 Impact categories description

\begin{tabular}{ll}
\hline Impact category & Impact category indicator \\
\hline Global warming potential (GWP) & $\mathrm{kg} \mathrm{CO}_{2}$ equivalent \\
Acidification potential (AP) & $\mathrm{kg} \mathrm{SO}_{2}$ equivalent \\
Photochemical ozone creation potential (POCP) & $\mathrm{kg}$ ethene equivalent \\
Eutrophication potential (EP) & $\mathrm{kg}$ phosphate equivalent \\
Abiotic depletion potential-elements (ADP-Elements) & $\mathrm{kg} \mathrm{Sb}$ equivalent \\
Abiotic depletion potential-fossil fuels (ADP-fossil fuels) & $\mathrm{MJ}$ \\
Water depletion (WD) & $\mathrm{m}^{3}$ \\
\hline
\end{tabular}

scenario 2 in terms of the POCP and the lowest weight (32\%) under scenario 1 in terms of the AP. Soda shows the most impact (37\%) under scenario 2 in the EP and the lowest impact (4\%) under scenario 1 in the POCP. Summarizing the results of the raw material impacts and considering the above analysis of the impacts by phase, we can outline that, for each indicator, the weights of the raw materials mostly decrease under scenario 1 over the baseline scenario because their supply is reduced due to the increase in cullet use.

Among the energy carriers, natural gas exerts the most significant impact, used for melting glass in the furnace, which attains the highest weight (31\%) under scenario 1 of the GWP, while the greatest reduction, equal to $81 \%$, occurs under scenario 1 of the EP over the baseline scenario. Comparing the impact decrease of natural gas between scenarios 1 and 2, the greatest reduction emerges equal to $50 \%$ in the GWP, owing to the lightweighting option considered. The electrical energy attains the highest weight of the impact (10\%) under scenario 1 of the GWP and the largest reduction (93\%) under scenario 2 of the GWP. It should be noted that, for all impact indicators, compared with scenario 1 , the energy carrier in general reveals a great reduction under scenario 2 owing to replacement of the Italian energy mix with PV energy.

The results related to the energy savings are in line with other studies, which illustrate that each $10 \%$ replacement of the sand mixture, soda and oxides with glass cullet saves $2.5 \%$ of the energy needed for the chemical transformation occurring in the melting furnace (Gallego-Schmid et al. 2018; Vellini and Savioli 2009).

For the purposes of this study, it was also necessary to compare our analysis results with those available in the literature, some of which are mentioned in section 2. To this end, we conducted a comparison of a significant environmental indicator for the glass industry: the global warming potential (Table 5).

Comparing the primary data available in the literature, the GWP under the baseline scenario $\left(1.11 \mathrm{E}+00 \mathrm{~kg} \mathrm{CO}_{2} \mathrm{eq}\right)$ is in line with the results of other studies, despite the different rates of cullet use and the differences in assumptions and methodology. In the Owens-Illinois LCA study (Avery et al. 2017), the GWP was $1.047 \mathrm{E}+00 \mathrm{~kg} \mathrm{CO}$ eq at a cullet use of approximately $37.8 \%$, while in the GPI report (2010), the GWP was $1.25 \mathrm{E}+00 \mathrm{~kg} \mathrm{CO}_{2}$ eq considering a $23 \%$ cullet use. In contrast, the FEVE study ( 2016) showed a slightly lower value than ours, in particular, a value of $9.50 \mathrm{E}-01 \mathrm{~kg} \mathrm{CO}$ eq at a cullet use of approximately $32 \%$. This circumstance is probably due to the difference between the European and Italian energetic mixes considered, which highly affects the $\mathrm{CO}_{2}$ emissions, especially at the core phase. In particular, FEVE used an average European mix for energy generation with a rate of natural gas $(23 \%)$ lower than that in the Italian energy mix (approximately $35 \%$ ) and a rate of nuclear energy equal to $11.4 \%$,

Fig. 6 Graphical comparisons of environmental indicators in different scenarios

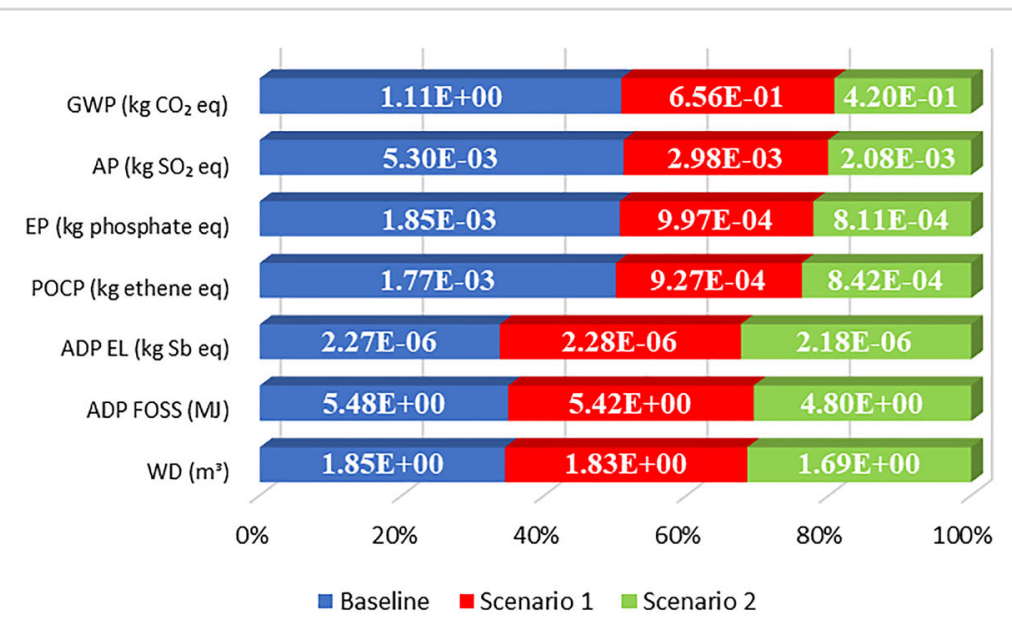


Table 4 Value comparisons of environmental indicators in different scenarios

\begin{tabular}{|c|c|c|c|c|c|}
\hline Assessment category & Scenario & Upstream & Core & Downstream & Total impacts \\
\hline Global warming potential & Baseline & $6.45 \mathrm{E}-01$ & 4.63E-01 & 2.91E-04 & $1.11 \mathrm{E}+00$ \\
\hline \multirow[t]{2}{*}{$\mathrm{kg} \mathrm{CO}_{2}$ equivalent } & Scenario 1 & $3.21 \mathrm{E}-01$ & $3.34 \mathrm{E}-01$ & 2.91E-04 & $6.56 \mathrm{E}-01$ \\
\hline & Scenario 2 & $3.10 \mathrm{E}-01$ & $1.09 \mathrm{E}-01$ & 2.91E-04 & 4.20E-01 \\
\hline Acidification potential & Baseline & $3.24 \mathrm{E}-03$ & $2.06 \mathrm{E}-03$ & $1.50 \mathrm{E}-06$ & $5.30 \mathrm{E}-03$ \\
\hline \multirow[t]{2}{*}{$\mathrm{kg} \mathrm{SO}_{2}$ equivalent } & Scenario 1 & $1.65 \mathrm{E}-03$ & $1.32 \mathrm{E}-03$ & $1.50 \mathrm{E}-06$ & $2.98 \mathrm{E}-03$ \\
\hline & Scenario 2 & $1.57 \mathrm{E}-03$ & $5.13 \mathrm{E}-04$ & $1.50 \mathrm{E}-06$ & $2.08 \mathrm{E}-03$ \\
\hline Eutrophication potential & Baseline & $1.52 \mathrm{E}-03$ & $3.26 \mathrm{E}-04$ & 4.26E-07 & $1.85 \mathrm{E}-03$ \\
\hline \multirow[t]{2}{*}{$\mathrm{kg}$ phosphate equivalent } & Scenario 1 & $7.80 \mathrm{E}-04$ & $2.17 \mathrm{E}-04$ & $4.26 \mathrm{E}-07$ & 9.97E-04 \\
\hline & Scenario 2 & 7.42E-04 & $6.87 \mathrm{E}-05$ & $4.26 \mathrm{E}-07$ & $8.11 \mathrm{E}-04$ \\
\hline Photochemical ozone creation potential & Baseline & $1.62 \mathrm{E}-03$ & $1.50 \mathrm{E}-04$ & $1.53 \mathrm{E}-07$ & $1.77 \mathrm{E}-03$ \\
\hline \multirow[t]{2}{*}{$\mathrm{kg}$ ethene equivalent } & Scenario 1 & 8.27E-04 & 9.97E-05 & $1.53 \mathrm{E}-07$ & $9.27 \mathrm{E}-04$ \\
\hline & Scenario 2 & 7.87E-04 & $5.48 \mathrm{E}-05$ & $1.53 \mathrm{E}-07$ & 8.42E-04 \\
\hline Abiotic Depletion Potential-Elements & Baseline & $2.24 \mathrm{E}-06$ & $3.01 \mathrm{E}-08$ & $8.58 \mathrm{E}-10$ & 2.27E-06 \\
\hline \multirow[t]{2}{*}{$\mathrm{kg}$ Sb equivalent } & Scenario 1 & $2.25 \mathrm{E}-06$ & $2.83 \mathrm{E}-08$ & $8.58 \mathrm{E}-10$ & $2.28 \mathrm{E}-06$ \\
\hline & Scenario 2 & 2.14E-06 & $3.76 \mathrm{E}-08$ & $8.58 \mathrm{E}-10$ & $2.18 \mathrm{E}-06$ \\
\hline Abiotic depletion potential-fossil fuels & Baseline & $4.27 \mathrm{E}+00$ & $1.21 \mathrm{E}+00$ & $4.44 \mathrm{E}-03$ & $5.48 \mathrm{E}+00$ \\
\hline \multirow[t]{2}{*}{ MJ } & Scenario 1 & $4.28 \mathrm{E}+00$ & $1.14 \mathrm{E}+00$ & 4.44E-03 & $5.42 \mathrm{E}+00$ \\
\hline & Scenario 2 & $4.06 \mathrm{E}+00$ & 7.37E-01 & 4.44E-03 & $4.80 \mathrm{E}+00$ \\
\hline Water depletion & Baseline & $1.54 \mathrm{E}+00$ & $3.08 \mathrm{E}-01$ & $2.27 \mathrm{E}-04$ & $1.85 \mathrm{E}+00$ \\
\hline \multirow[t]{2}{*}{$\mathrm{m}^{3}$} & Scenario 1 & $1.54 \mathrm{E}+00$ & $2.90 \mathrm{E}-01$ & $2.27 \mathrm{E}-04$ & $1.83 \mathrm{E}+00$ \\
\hline & Scenario 2 & $1.46 \mathrm{E}+00$ & $2.28 \mathrm{E}-01$ & $2.27 \mathrm{E}-04$ & $1.69 \mathrm{E}+00$ \\
\hline
\end{tabular}

which is not used in Italy, thus explaining the lower GWP data in the FEVE report than our GWP data.

Table 5 also provides the GWP values corresponding to the use of $65-70 \%$ cullets: the highest values of $9.20 \mathrm{E}-01$ and 8.48E-01 occur in the Avery et al. (2017) and GPI (2010) studies, respectively, while the FEVE (2016) value (6.70E01 ) is the closest to our analysis result (6.56E-01), in which a $66 \%$ cullet use is assumed.

Analysing the regional context where over 96,000 t of unused post-consumer cullets are available and considering the baseline scenario, which requires approximately $37,500 \mathrm{t}$ of external cullets, the supply assumption in the Apulia region is validated (Osservatorio Rifiuti Regione Puglia 2020).

According to our defined scenarios 1 and 2, the required cullet quantity is $117,000 \mathrm{t}$ per year. Considering that approximately $20,000 \mathrm{t}$ is covered by internal cullets, from the production process, the external cullet supply has to be $97,000 \mathrm{t}$, which can be covered by the regional supply at a rate of $72 \%$, approximately 70,000 t, and the residual part can be supplied by neighbouring regions to Apulia, where there are currently no glass manufacturing plants, to guarantee a short and sustainable supply chain. It must be stressed that, as mentioned above, the cullets recovered by differentiated collection in Apulia in 2022 is expected to reach $137,577 \mathrm{t}$, so the amount of the regional cullet supply $(70,000 \mathrm{t})$ is a conservative estimate derived from the necessity of supplying the other large manufacturing plant located in Apulia.
Moreover, in light of a higher national target of differentiated glass collection, equal to an average of $36.2 \mathrm{~kg} /$ inhabitant, a further increase in the Apulian indicator of differentiated collection (currently equal to $27.9 \mathrm{~kg}$ /inhabitant) is expected to be reached (CoReVe 2019b), also driven by a public funding strategy to improve the differentiated waste collection implemented in southern Italy in recent years (Testa et al. 2017). Additionally, the increase in cullet recycling approaches a closed-loop solution (Simon et al. 2016).

It must be stressed that suitable differentiated collection and selection is important to guarantee the quality of the entire recycling process because the contamination of cullets or the presence of glass from solar panels or flat glass could negatively affect the batch stream.

Linked to the increasing use of cullets from the regional supply is the decrease in the transport of raw materials (sand and soda) by ships, which dramatically reduces the ratio in terms of tons $/ \mathrm{km}$, thus enhancing the environmental benefits.

The limitation of the research is that an economic evaluation of the three scenarios (using LCC, for example) has not been undertaken. A comparison of the corresponding economic results could allow a full analysis and serve as a complete management tool to choose better options with regard to the production system investigated. These areas can be examined in future research. Another option for future analysis is to consider the end-point approach in the LCA study for a deeper understanding of the environmental issues facing glass manufacturing. 
Fig. 7 The most impacting inputs per different scenarios
GWP
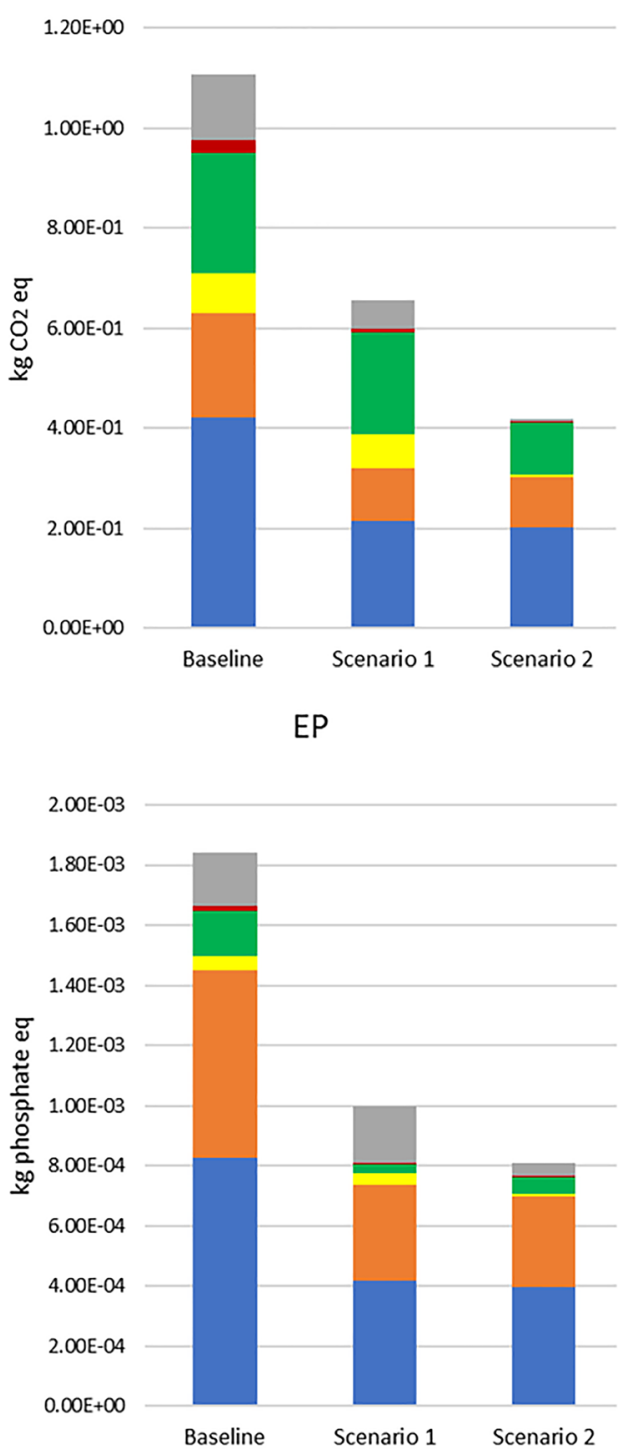

AP

$6.00 \mathrm{E}-03$

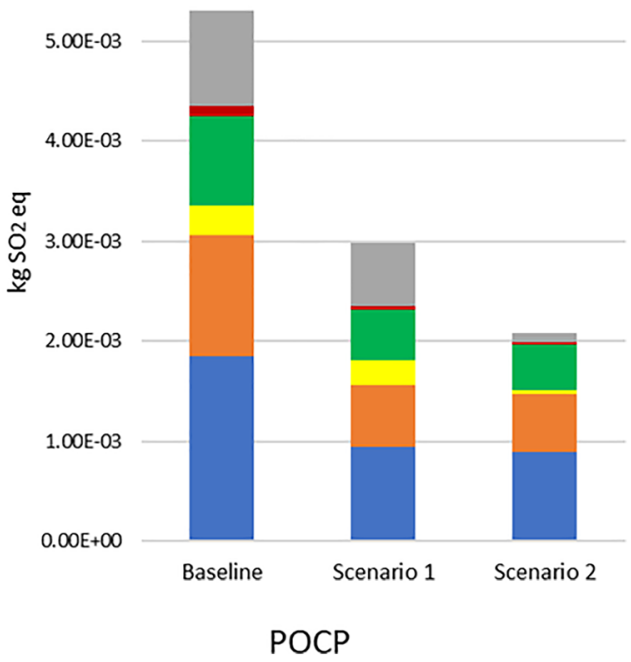

2.00E-03

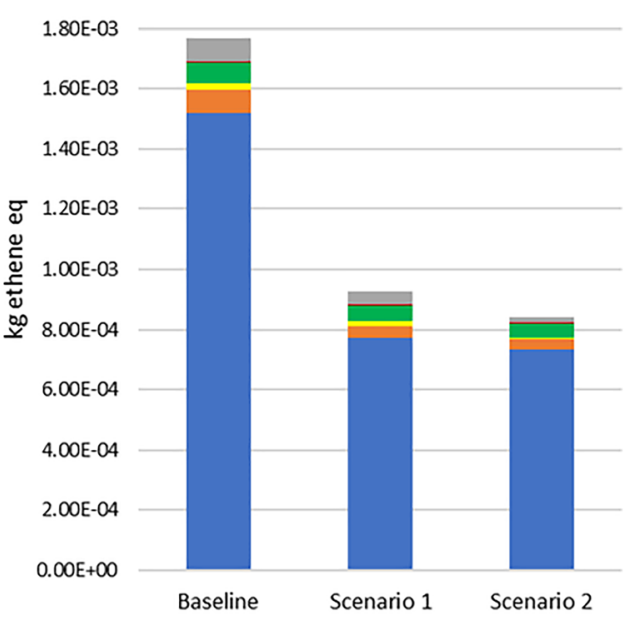

a Calcium carbonate $\square$ Soda Electrical Energy $\quad$ Natural Gas Diesel $\square$ Other

Table 5 Presentation of the main LCA studies using primary data. Functional unit: $1 \mathrm{~kg}$ formed and finished glass. Source: personal elaboration by the authors on GPI (2010); FEVE (2016); Avery et al. (2017)

\begin{tabular}{lllll}
\hline Study & Year & $\%$ Cullet & GWP-kg CO $\mathrm{Cq}_{2}$ & Boundaries \\
\hline Global Packaging Institute (GPI) & 2010 & $23 \%$ & $1.25 \mathrm{E}+00$ & Cradle to cradle \\
& & $65-70 \%$ & $8.48 \mathrm{E}-01$ & Cradle to cradle \\
European Container Glass & 2016 & $33 \%$ & $9.50 \mathrm{E}-01$ & Cradle to cradle \\
$\quad$ Federation (FEVE) & & $65-70 \%$ & $6.70 \mathrm{E}-01$ & Cradle to cradle \\
Avery et al. & 2017 & $37.80 \%$ & $1.047 \mathrm{E}+00$ & Cradle to gate + end of life \\
& & $65-70 \%$ & $9.20 \mathrm{E}-01$ & Cradle to gate + end of life \\
Gallucci et al. (present study) & 2020 & $32 \%$ & $1.11 \mathrm{E}+00$ & Cradle to grave \\
& & $66 \%$ & $6.56 \mathrm{E}-01$ & Cradle to grave \\
\hline
\end{tabular}




\section{Conclusion and future perspectives}

The LCA allowed for the evaluation of the environmental performance of hollow glass production for beverage and food packaging in a manufacturing plant. Based on the current environmental performance highlighted under the baseline scenario, certain improvements were obtained under two realistic scenarios built according to the increase in raw material, energy and emission savings. The main reduction among the impact indicators occurred in the GWP, the results of which showed a reduction of $41 \%$ considering an increased use of cullets (scenario 1) over the baseline scenario and a further reduction of $36 \%$ if PV energy use and lightweighting (scenario 2) are additionally considered. Based on the study findings, the most impactful phase was the upstream phase, where the greatest weight was represented by calcium carbonate, which could be reduced by the introduction of more recycling and technological improvement, as highlighted by the GWP reduction under scenario 2 , which was approximately $52 \%$ lower than that at the upstream phase under the baseline scenario. Moreover, considering that the 5\% lightweighting rate adopted in the scenario resulted in a sharp reduction, even if lower than that resulting from the PV energy use, a lightweighting rate of up to $30 \%$, as suggested in the scientific literature, could influence the LCA results even more.

Energy carriers continue to exert a high impact, partially mitigated by the proposed options. Natural gas is the most impactful at the core phase, also due to its large quantities used in this process. The high energy intensity in the glass industry continues to be a major issue, both in terms of $\mathrm{CO}_{2}$ emissions and cost, which is currently equal to over $20 \%$ of the total costs.

Regarding the use of cullets, our results confirmed that it notably reduces the environmental impacts of glass production and that suitable differentiated collection must be achieved for a higher efficiency and to guarantee the territorial range of the supply chain.

In any case, it must be stressed that the glass industry is a very $\mathrm{CO}_{2}$ intensive sector, which is the reason why the GWP indicator and its variations have been particularly investigated and addressed in this paper. This consideration suggests the need for a deep rethinking of the entire glass supply chain by all stakeholders and consumers. In recent years, moreover, the food industry has been increasingly characterized by many process changes, with more attention being paid to food waste and developing innovative systems to minimize the negative impacts of food packaging, in line with the latest European guidelines provided for both the design for environment and circular economy strategies in industrial sectors.

Acknowledgements Open access funding provided by Università degli Studi di Bari Aldo Moro within the CRUI-CARE Agreement. A special thanks to Dr. Leonardo Spinelli (plant manager) and Dr. Vito Nicola Tatone (EHS Coordinator \& Energy Team Leader) who greatly assisted the research study.

Authors' contributions Teodoro Gallucci: conceptualization, investigation, data curation, writing-original draft preparation. Giovanni Lagioia: writing-review and editing. Paolo Piccinno: data curation and validation. Amedeo Lacalamita: software and data curation. Andrea Pontrandolfo: visualisation, validation and writing-original draft preparation. Annarita Paiano (corresponding author): conceptualization, methodology, writingoriginal draft preparation and supervision.

Open Access This article is licensed under a Creative Commons Attribution 4.0 International License, which permits use, sharing, adaptation, distribution and reproduction in any medium or format, as long as you give appropriate credit to the original author(s) and the source, provide a link to the Creative Commons licence, and indicate if changes were made. The images or other third party material in this article are included in the article's Creative Commons licence, unless indicated otherwise in a credit line to the material. If material is not included in the article's Creative Commons licence and your intended use is not permitted by statutory regulation or exceeds the permitted use, you will need to obtain permission directly from the copyright holder. To view a copy of this licence, visit http://creativecommons.org/licenses/by/4.0/.

\section{References}

Accorsi R, Versari L, Manzini R (2015) Glass vs plastic: life cycle assessment of extra virgin olive oil bottles across global supply chains. Sustainability 7:2818-2840. https://doi.org/10.3390/su7032818

Amienyo D, Camilleri C, Azapagic A (2014) Environmental impacts of consumption of Australian red wine in the UK. J Clean Prod 72: 110-119. https://doi.org/10.1016/j.jclepro.2014.02.044

Assovetro (2019) Dati di settore. http://www.assovetro.it/dati-di-settore/. Accessed 12 Mar 2019

Assovetro (2020) Rapporto di sostenibilità 2020. https://www.assovetro. it/wp-content/uploads/2020/02/report-completo-low-min2.pdf. 2020/. Accessed 24 Mar 2020

Auer J, Bey N, Chafer JM (2017) Combined life cycle assessment and life cycle costing in the eco-care-matrix: a case study on the performance of a modernized manufacturing system for glass containers. J Clean Prod 141:99-109. https://doi.org/10.1016/j.jclepro.2016.08.096

Avery G, Bhaduri S, Nordmeyer J (2017) Life cycle analysis of glass containers. Prepared by Owens-Illinois, Inc., pp 1-74

Balzarotti S, Maviglia B, Biassoni F, Ciceri MR (2015) Glass vs. plastic: affective judgments of food packages after visual and haptic exploration. Procedia Manuf 3:2251-2258. https://doi.org/10.1016/j. promfg.2015.07.369

Blengini GA, Busto M, Fantoni M, Fino D (2012) Eco-efficient waste glass recycling: integrated waste management and green product development through LCA. Waste Manag 32:1000-1008. https:// doi.org/10.1016/j.wasman.2011.10.018

Butler JH, Hooper PD (2019) Glass waste. In: Waste, 2nd edn. Academic press, pp 307-322

Caldeira C, De Laurentiis V, Corrado S, van Holsteijn F, Sala S (2019) Quantification of food waste per product group along the food supply chain in the European Union: a mass flow analysis. Resour Conserv Recycl 149:479-488. https://doi.org/10.1016/j.resconrec.2019.06.011

CoReVe (2019a) Piano specifico di Prevenzione 2019 - maggio 2019. https:// coreve.it/wp-content/uploads/2019/06/PspCorevemaggio2019dati2018-31maggio2019.pdf. Accessed 31 Mar 2020

CoReVe (2019b) Risultati 2018 Sintesi Programma Specifico di Prevenzione 2019. https://coreve.it/wp-content/uploads/2019/10/ PSP_20182019_web.pdf. Accessed 20 Apr 2020

Cruz AG, Faria JAF, Van Dender AGF (2007) Packaging system and probiotic dairy foods. Food Res Int 40:951-956. https://doi.org/10. 1016/j.foodres.2007.05.003

Del Borghi A, Gallo M, Magrassi F (2016) Glass packaging design and life cycle assessment: deep review and guideline for future 
developments) Reference Module in Food Sci:1-9. https://doi.org/ 10.1016/B978-0-08-100596-5.21008-1

Environdec (2018) Product Category Rules (PCR), PCR Basic Module CPC 37 Glass and glass products and other non-metallic products n.e.v 3.0, Version 3.0

Eurostat (2019) Packaging waste by waste management operations and waste flow. https://ec.europa.eu/eurostat/web/products-datasets/-/ env_waspac. Accessed 10 Jan 2020

Eurostat (2020) Recycling rates for packaging waste. https://ec.europa. eu/eurostat/databrowser/view/ten00063/default/table?lang=en. Accessed 17 Jan 2020

FEVE - The European Container Glass Federation (2010) The Gob, FEVE publishes comprehensive life cycle assessment. https://feve. org/wp-content/uploads/2016/04/The-gob-issue-september-2010. pdf. Accessed 12 Oct 2019

FEVE - The European Container Glass Federation (2015) EU container glass production growth shows industry resilience. https://feve.org/ wp-content/uploads/2016/04/EU-container-glass-productiongrowth-shows-industry-resilience.pdf. Accessed 10 Mar 2019

FEVE - The European Container Glass Federation (2016) Recycling: why glass always has a happy $\mathrm{CO}_{2}$ ending. https://feve.org/ recycling-glass-always-happy-co2-ending/. Accessed 27 Oct 2019

FEVE - The European Container Glass Federation (2019) Record collection of glass containers for recycling hits $76 \%$ in the EU. https://feve. org/record-collection-of-glass-containers-for-recycling-hits-76-inthe-eu/. Accessed 1 Nov 2019

FEVE - The European Container Glass Federation (2020) The European container glass industry. https://feve.org/about-feve/library/. Accessed 10 Feb 2020

Finkbeiner M (2012) Gap analysis for the life cycle assessment of container packaging. Final Report for FEVE - the European Container Glass Federation. ISBN 978-3-00-041338-4

Franco I, Falqué E (2016) glass packaging. Reference Module in Food Sci, Elesevier https://doi.org/10.1016/B978-0-08-100596-5.03371-0

Freire F, Thore S, Ferrao P (2001) Life cycle activity analysis: logistics and environmental policies for bottled water in Portugal. ORSpektrum 23:159-182. https://doi.org/10.1007/PL00013340

Fresán U, Errendal S, Craig WJ, Sabaté J (2019) Does the size matter? A comparative analysis of the environmental impact of several packaged foods. Sci Total Environ 687:369-379. https://doi.org/10. 1016/j.scitotenv.2019.06.109

Gallego-Schmid A, Mendoza JMF, Azapagic A (2018) Improving the environmental sustainability of reusable food containers in Europe. Sci Total Environ 628-629:979-989. https://doi.org/10.1016/j. scitotenv.2018.02.128

Garfi M, Cadena E, Sanchez-Ramos D, Ferrer I (2016) Life cycle assessment of drinking water: comparing conventional water treatment, reverse osmosis and mineral water in glass and plastic bottles. J Clean Prod 137:997-1003. https://doi.org/10.1016/j.jclepro.2016.07.218

GPI - Glass Packaging Institute (2010) Environmental overview, complete life cycle assessment of North American container glass. http:// www.gpi.org/sites/default/files/LCA\%20-\%20GPI2010\%20-\% 20compressed.pdf. Accessed 10 Oct 2019

Grisan (2018) Gli imballaggi nell'economia circolare. http://www.conai. org/wp-content/uploads/dlm_uploads/2018/11/CONAI_Report Sostenibilit\%C3\%A0_2018.pdf. Accessed 3 Apr 2019

Guiso A, Parenti A, Masella P, Guerrini L, Baldi F, Spugnoli P (2016) Environmental impact assessment of three packages for high-quality extra-virgin olive oil. J Agric Eng 47:191-196. https://doi.org/10. 4081/jae.2016.515

Humbert S, Rossi V, Margni M (2009) Life cycle assessment of two baby food packaging alternatives: glass jars vs. plastic pots. Int J Life Cycle Assess 14:95-106. https://doi.org/10.1007/s11367-008-0052-6

Ingrao C, Faccilongo N, Valenti F, De Pascale G, Di Gioia L, Messineo A, Arcidiacono C (2019) Tomato puree in the Mediterranean region: an environmental life cycle assessment, based upon data surveyed at the supply chain level. J Clean Prod 233:292-313. https://doi.org/ 10.1016/j.jclepro.2019.06.056

ISO 14040 (2006) Environmental management e life cycle assessment. Principles and framework-requirements and guidelines

ISO 14044 (2018). Environmental management e life cycle assessment. Requirements and guidelines

Jayamanne VS, Adams MR (2004) Survival of probiotic bifidobacteria in buffalo curd and their effect on sensory properties. Int J Food Sci Tech 39:719-725. https://doi.org/10.1111/j.1365-2621.2004.00835.x

Kobayashi M (2016a) Assessing risks and defects of glass packaging. Reference Module in Food Sci, Elsevier. https://doi.org/10.1016/ B978-0-08-100596-5.03199-1

Kobayashi M (2016b) Glass packaging properties and attributes. Reference Module in Food Sci, Elsevier. https://doi.org/10.1016/ B978-0-08-100596-5.03191-7

Manfredi M, Vignali G (2014) Life cycle assessment of a packaged tomato puree: a comparison of environmental impacts produced by different life cycle phases. J Clean Prod 73:275-284. https://doi.org/ 10.1016/j.jclepro.2013.10.010

Markwardt S, Wellenreuther F (2016) Sensitivity analysis as a tool to extend the applicability of LCA findings. Int J Life Cycle Assess 21:1148-1158. https://doi.org/10.1007/s11367-016-1094-9

Molina-Besch K, Wikström F, Williams H (2019) The environmental impact of packaging in food supply chains - does life cycle assessment of food provide the full picture? Int J Life Cycle Assess 24:3750. https://doi.org/10.1007/s11367-018-1500-6

Moraga G, Huysveld S, Mathieux F, Blengini GA, Alaerts L, Van Acker $\mathrm{K}$, deMeester S, Dewulf J (2019) Circular economy indicators: what do they measure? Resour Conserv Recycl 146:452-461. https://doi. org/10.1016/j.resconrec.2019.03.045

Neto B, Dias AC, Machado M (2013) Life cycle assessment of the supply chain of a Portuguese wine: from viticulture to distribution. Int J Life Cycle Assess 18:590-602. https://doi.org/10.1007/s11367-012-0518-4

Osservatorio Rifiuti Regione Puglia (2020) Dati R.S.U. in Puglia - Anno 2019. $\mathrm{http} / /$ ambiente.regione.puglia.it/portal/portale_orp/Osservatorio+Rifiuti/ Osservatorio+Rifiuti+Cittadino/RSU+in+Puglia/OrpCittadinoWindow? entity=rsupuglia\&action=2. Accessed $22 \mathrm{Feb} 2020$

Point E, Tyedmers P, Naugler C (2012) Life cycle environmental impacts of wine production and consumption in Nova Scotia, Canada. J Clean Prod 27:11-20. https://doi.org/10.1016/j.jclepro.2011.12.035

Schmitz A, Kamiński J, Scalet BM, Soria A (2011) Energy consumption and $\mathrm{CO}_{2}$ emissions of the European glass industry. Energy Policy 39:142-155. https://doi.org/10.1016/j.enpol.2010.09.022

Simon B, Amor MB, Földényi R (2016) Life cycle impact assessment of beverage packaging systems: focus on the collection of postconsumer bottles. J Clean Prod 112:238-248. https://doi.org/10. 1016/j.jclepro.2015.06.008

Testa M, Malandrino O, Sessa MR, Supino S, Sica D (2017) Long-term sustainability from the perspective of cullet recycling in the container glass industry: evidence from Italy. Sustainability 9:1752-1771. https://doi.org/10.3390/su9101752

Vellini M, Savioli M (2009) Energy and environmental analysis of glass container production and recycling. Energy 34:2137-2143. https:// doi.org/10.1016/j.energy.2008.09.017

Vinci G, D'Ascenzo F, Esposito A, Musarra M, Rapa M, Rocchi A (2019a) A sustainable innovation in the Italian glass production: LCA and Eco-Care Matrix evaluation. J Clean Prod 223:587-595. https://doi.org/10.1016/j.jclepro.2019.03.124

Vinci G, D’Ascenzo F, Esposito A, Musarra M (2019b) Glass beverages packaging: innovation by sustainable production in trends in beverage packaging. Academic Press 16:105-133. https://doi.org/10. 1016/B978-0-12-816683-3.00005-0

Publisher's note Springer Nature remains neutral with regard to jurisdictional claims in published maps and institutional affiliations. 